University of Nebraska - Lincoln

DigitalCommons@University of Nebraska - Lincoln

$6-2006$

\title{
Factors Influencing Soil Invertebrate Communities in Riparian Grasslands of the Central Platte River Floodplain
}

Craig A. Davis

Platte River Whooping Crane Maintenance Trust, craig.a.davis@okstate.edu

Jane E. Austin

U.S. Geological Survey, jaustin@usgs.gov

Deborah A. Buhl

U.S. Geological Survey, dbuhl@usgs.gov

Follow this and additional works at: https://digitalcommons.unl.edu/usgsnpwrc

Part of the Other International and Area Studies Commons

Davis, Craig A.; Austin, Jane E.; and Buhl, Deborah A., "Factors Influencing Soil Invertebrate Communities in Riparian Grasslands of the Central Platte River Floodplain" (2006). USGS Northern Prairie Wildlife Research Center. 2.

https://digitalcommons.unl.edu/usgsnpwrc/2

This Article is brought to you for free and open access by the US Geological Survey at DigitalCommons@University of Nebraska - Lincoln. It has been accepted for inclusion in USGS Northern Prairie Wildlife Research Center by an authorized administrator of DigitalCommons@University of Nebraska - Lincoln. 


\title{
FACTORS INFLUENCING SOIL INVERTEBRATE COMMUNITIES IN RIPARIAN GRASSLANDS OF THE CENTRAL PLATTE RIVER FLOODPLAIN
}

\author{
Craig A. Davis, ${ }^{1,3}$ Jane E. Austin, ${ }^{2}$ and Deborah A. Buhl ${ }^{2}$ \\ ${ }^{1}$ Platte River Whooping Crane Maintenance Trust \\ 6611 W. Whooping Crane Drive \\ Wood River, Nebraska, USA 68883 \\ ${ }^{2} U$. S. Geological Survey \\ Northern Prairie Wildlife Research Center \\ $871137^{\text {th }}$ Street $S E$ \\ Jamestown, North Dakota, USA 58401 \\ ${ }^{3}$ Present address: \\ Department of Zoology \\ 430 Life Science West \\ Oklahoma State University \\ Stillwater, Oklahoma, USA 74078 \\ E-mail: craigda@okstate.edu
}

\begin{abstract}
In the Platte River Valley of central Nebraska, USA, riparian grasslands (also known as wet meadows) have been severely impacted by a reduction in river flows, causing lower ground-water levels and altered seasonal hydroperiods. The potential impacts of these hydrologic changes, as well as the environmental factors that influence wet meadow soil invertebrate communities, are not well understood. An understanding of the ecological processes that influence these invertebrate communities is crucial for maintaining and restoring wet meadows along the Platte River. Our objectives were to describe the soil invertebrate community of wet meadows throughout the growing season and to examine the relative roles of abiotic factors in determining patterns in invertebrate community structure. We conducted the study in 12 wet meadows along the Platte River during 1999 and 2000. We identified 73 invertebrate taxa; 39 were considered soil inhabitants. Total biomass was primarily composed of earthworms, Scarabaeidae, Isopoda, and Elateridae, with earthworms and Scarabaeidae accounting for $>82 \%$. Differences in river flow and precipitation patterns influenced some soil invertebrates. Earthworms and Scarabaeidae declined dramatically from 1999 (wet year) to 2000 (dry year). The topographic gradient created by the ridge-swale complex affected several soil invertebrate taxa; Scarabaeidae, Diplopoda, and Lepidoptera biomasses were greatest on drier ridges, while Tipulidae and Isopoda biomasses were greatest in wetter sloughs. Responses of earthworm taxa to the topographic gradient were variable, but generally, greater biomasses occurred on ridges and mid-elevations. Water-table depth and soil moisture were the most important variables influencing wet meadow soil invertebrates. Because these communities are linked to the hydrologic processes of the Platte River, future alterations of wet meadow hydrology could shift the distribution patterns of many of these invertebrates and possibly eliminate more moisture-tolerant taxa. To maintain wet meadows and their biotic communities, flow management should focus on regaining as much as possible of the former hydrograph through properly timed flows that provide an adequate hydrologic regime for wet meadows. In addition, restoration of wet meadows will depend on restoring the natural topography of wet meadows.
\end{abstract}

Key Words: arthropod, riparian grassland, Nebraska, Platte River, soil invertebrate, wet meadow

\section{INTRODUCTION}

Soil invertebrates play an important role by affecting the structure and function of riparian grassland ecosystems. In particular, soil invertebrates link primary production to secondary consumers, play a critical role in nutrient cycling through facilitating decom- position of organic matter and decaying roots, improve soil fertility and structure, influence vegetation species composition, and alter primary production (Seastedt and Crossley 1984, Brown and Gange 1990, Edwards and Bohlen 1996, Lavelle and Spain 2001). It is imperative that ecologists and conservationists understand the impacts of anthropogenic and natural distur- 
bances on these communities. Disturbances can influence soil invertebrate communities through their effects on environmental factors such as soil moisture, organic matter, soil chemistry, vegetation composition, and root biomass (Blair et al. 2000). An understanding of how abiotic factors are influenced by disturbance and how these factors influence soil invertebrates will not only allow us to predict the potential impacts of future environmental changes on soil invertebrates (Blair et al. 2000), but will also allow us to evaluate the suitability of restored grasslands for soil invertebrate communities.

In the Platte River valley of central Nebraska, USA, anthropogenic disturbances have had a major impact on floodplain riparian grasslands, also referred to as wet meadows. These grasslands, which are hydrologically connected to river flows, are characterized by high water tables, poor drainage, nutrient-rich soils, and a variable topographic gradient that includes wetland swales and relatively dry ridge tops (Jelinski and Currier 1996). During the last 100-150 years, the Platte River has undergone dramatic morphologic and hydrologic changes (Williams 1978, Eschner et al. 1981, Johnson 1994, Currier 1997). The construction of large mainstem dams on the North Platte River and the development of surface waters and ground water for cropland irrigation and municipal and industrial uses have caused a decline of river flows. Since 1915, peak flows have decreased from an average of $550 \mathrm{~m}^{3}$ $\mathrm{sec}^{-1}$ to an average of $150 \mathrm{~m}^{3} \mathrm{sec}^{-1}$, and nearly $70 \%$ of the flow through central Nebraska has been lost to water development (Williams 1978, Eschner et al. 1981). These reduced flows have had a profound impact on wet meadows by lowering ground-water levels and altering seasonal hydroperiods (Hurr 1983, Currier and Ziewitz 1986, Wesche et al. 1994). Although the large-scale effects of these hydrologic changes are readily apparent along the Platte River (i.e., conversion of $75-80 \%$ of the wet meadow acreage for agricultural land [Sidle et al. 1989]), localized effects of these changes on the biological communities and ecological processes in wet meadows have not been well studied (Nagel and Harding 1987, Davis and Vohs 1993).

This ecosystem has been the focus of major conservation efforts because the Platte River is one of the most impacted ecosystems in North America and provides critical habitat for several endangered and threatened species (whooping crane [Grus americana, L.], least tern [Sterna antillarum, Lesson], and piping plover [Charadrius melodus, L.]), as well as numerous migratory birds. Colorado, Nebraska, and Wyoming and the federal government have developed a basinwide plan to manage Platte River flows (Cooperative Agreement 1997). One component of this plan targets wet meadows as critical habitats requiring conserva- tion, management, and restoration. However, these efforts have largely been without the benefit of information about how biological communities are linked to the physical environment.

Our objectives were to describe the soil invertebrate community of wet meadows throughout the growing season and to examine the relative roles of abiotic factors (e.g., soil characteristics, water-table depth, litter biomass, and root biomass) in determining patterns in soil invertebrate community structure. This study has implications for restoration of riparian grasslands throughout the Great Plains and provides information about belowground communities, which is generally lacking.

\section{METHODS}

Study Area

We conducted the study in 12 wet meadows along a $130-\mathrm{km}$ reach of the Platte River in central Nebraska, USA $\left(40^{\circ} 49^{\prime} \mathrm{N}, 98^{\circ} 23^{\prime} \mathrm{W}\right)$. Within this area, elevations range from $575 \mathrm{~m}$ asl to $635 \mathrm{~m}$ asl. Wet meadows along the Platte River are dissected by numerous sloughs fed by high ground-water levels and surface runoff from precipitation throughout the year. Sloughs are filled with water during late spring when river flows are highest, and sloughs are normally dry during summer when river flows are lowest. Land-management practices of wet meadows include cattle grazing, haying, and extended resting (4-8 years). Stocking rates of cattle were generally 0.3 animal-unit-months per hectare. Prescribed burns were periodically combined with each management practice. Because these management practices were rotationally applied to wet meadows every 3-4 years and the same management practice was not consistently applied each year, we chose to focus our study on the abiotic factors that influence soil invertebrate communities. We recognize that management practices can influence soil invertebrate communities, but this influence is usually directed through how these practices influence abiotic factors, which we measured.

Annual precipitation within the study area is about $63 \mathrm{~cm}$, with most of the precipitation occurring during spring and summer (National Climatic Data Center 2000). Average daily temperatures during study months were $9.7^{\circ} \mathrm{C}$ (April), $16.8^{\circ} \mathrm{C}$ (May), $20.7^{\circ} \mathrm{C}$ (June), $25.3^{\circ} \mathrm{C}$ (July), $24.1^{\circ} \mathrm{C}$ (August) and $18.4^{\circ} \mathrm{C}$ (September) (National Climatic Data Center 2000).

Vegetation types in wet meadows follow a moisture gradient created by differences in elevation between wetter sloughs and drier ridges. In sloughs, the dominant plants are common spikerush (Eleocharis palustris, L.), Emory's sedge (Carex emoryi, Dewey), 
woolly sedge (C. pellita, Muhl ex Willd.), white panicle aster (Symphyotrichum lanceolatum, Willd.), water knotweed (Polygonum amphibium, L.), rice cutgrass (Leerzia oryzoides, L.), lanceleaf frogfruit (Phyla lanceolata, Michx.), and foxtail barley (Hordeum jubatum, L.), whereas needleleaf sedge (C. duriuscula, C. A. Mey.), Cuman ragweed (Ambrosia psilostachya, L.), purple poppymallow (Callirhoe involucrate, Michx.), narrowleaf stoneseed (Lithospermum incisum, Lehm.), Kentucky bluegrass (Poa pratensis, L.), and Heller's rosette grass (Dichanthelium oligosanthes, J. A. Schultes) are the dominant plants on ridges (Henszey et al. 2004). In the transitional zone between sloughs and ridges, the dominant plants are big bluestem (Andropogon gerardii, Vitman), little bluestem (Schizachyrium scoparium, Michx.), Indiangrass (Sorghastrum nutans, L.), switchgrass (Panicum virgatum, L.), intermediate wheatgrass (Thinopyrum intermedium, Host), and white heath aster (Symphyotrichum ericoides, L.) (Henszey et al. 2004).

\section{Soil Invertebrate Sampling}

We selected an individual slough-ridge elevation profile within each wet meadow for soil invertebrate sampling. Our goal was to collect soil invertebrates from a gradient of moisture levels (i.e., high, moderate, and low moisture) and plant communities (i.e., dry ridge, mesic prairie, and sedge meadow [Henszey et al. 2004]) representative of wet meadows throughout the Platte River valley. We established three transects for soil invertebrate sampling at the highest, middle, and lowest elevations along each slough-ridge profile within each wet meadow. Each transect was generally 20-25 m long. Paired ground-water wells were established at the lowest and highest elevations of each slough-ridge profile to determine ground-water levels during the study.

We collected soil invertebrates from five sampling points spaced at $50-\mathrm{cm}$ intervals along each transect during mid-late April (Period 1), early-mid June (Period 2), mid-late July (Period 3), and late August-early September (Period 4) in 1999 and 2000. At each sampling point, we visually estimated the percent cover of litter and measured litter depth to the nearest $0.5 \mathrm{~cm}$. We clipped any standing vegetation and collected litter from within a $25 \times 25 \mathrm{~cm}$ quadrat centered on the sampling point. Any visible invertebrates from the litter were removed and preserved in $80 \%$ ethanol. Following litter removal, we collected a $25 \times 25 \mathrm{~cm}$ and 20-cm-deep soil block from the sampling point using a spade (Davis and Vohs 1993, Edwards and Bohlen 1996) and placed the soil block in a plastic bag for transportation to a field laboratory. At each sampling point, we measured subsurface (10-cm depth) and sur- face temperatures using a soil thermometer and soil moisture at a 6-cm depth using a ThetaProbe moisture meter (accuracy $+2 \%$ soil moisture; Delta-T Devices, Cambridge, England). Ground-water levels were also measured from each of the paired ground-water wells using a fiberglass tape equipped with an electronic sensor (Henszey 1991).

Each soil block was transported to the field laboratory, where it was broken apart and all visible invertebrates were collected. After the soil block was hand sorted, it was placed in a tub of water and stirred to suspension. The suspension was then poured through a $1.0-\mathrm{mm}$ sieve, and invertebrates (i.e., macroarthropods and earthworms) retained on the sieve were removed. Earthworms were preserved following the method described by Fender (1985). All other invertebrates were preserved in $80 \%$ ethanol. During collection of invertebrates, we also removed roots by hand, which were later oven-dried at $60^{\circ} \mathrm{C}$ to constant mass to determine root biomass.

We collected a 10-cm-diameter and 20-cm-deep soil core adjacent to each sampling point during period 1 of each year to determine soil characteristics. These samples were sealed in a moisture-proof bag and frozen for later analysis at a commercial laboratory. Percent organic matter was determined by the WalkelyBlack method, total nitrogen $(\mathrm{N})$ by combustion analyzer, potassium $(\mathrm{K})$ by ammonium acetate extractable method, phosphorus (P) by sodium bicarbonate method, $\mathrm{pH}$ by using a 1:1 soil water ratio, and particle size by hydrometer method (B. Olsen, Olsen's Agricultural Laboratory, Incorporated, McCook, NE, personal communication; Westerman 1990).

Invertebrate taxa were identified to the family level except for earthworms, which were identified to genus or species level (Fender 1985, Stehr 1987, 1991). All invertebrates were counted and oven-dried at $60^{\circ} \mathrm{C}$ for at least $24 \mathrm{~h}$ to a constant mass $(0.001 \mathrm{~g})$. Voucher specimens are stored at the Platte River Whooping Crane Maintenance Trust, Grand Island, NE.

\section{Statistical Analyses}

Data were collected during two years, four periods each year, at three elevations at each of 12 sites. Unless otherwise noted, analyses were conducted separately for each period; therefore, each site-elevationyear combination was used as an observation for each analysis. Hereafter, this combination is referred to as a "location."

We used doubly repeated-measures analysis of variance (ANOVA) models to assess the effects of year, period, and elevation (high, mid, and low) on abiotic factors, total invertebrate biomass, and biomass of the 12 most abundant taxa. We used SAS version 8.2 
(SAS Institute 1999) for ANOVA and descriptive statistics; $\alpha$-level was set at 0.05 . Fisher's protected least significant differences were used to isolate differences in least-squares means (LSMEANS) following significant effects in ANOVAs (Milliken and Johnson 1992).

We used canonical correspondence analysis (CCA) to assess the relationship between invertebrate biomass and the measured abiotic factors (McCune and Grace 2002). All analyses were conducted using PC-ORD 4.26 (McCune and Mefford 1999). CCA is a direct gradient analysis that uses a combination of ordination and regression to define axes that are linear combinations of the abiotic factors that "best' explain the variation in the invertebrate data. Invertebrate biomass values were square-root transformed prior to analysis to reduce the influence of dominant taxa (ter Braak 1986). Rare taxa (i.e., taxa occurring in $<5 \%$ of the locations) were deleted prior to analysis (McCune and Grace 2002). One location in period 3 had very high and questionable soil temperatures; therefore, analyses for period 3 were conducted without this location. We used a $\ln (\mathrm{y})$ transformation for $\mathrm{N}, \mathrm{K}, \mathrm{P}$, organic matter, root mass, surface temperature, and subsurface temperature, and a $\ln (y+1)$ transformation for litter depth and litter mass because some litter depths were zero. We interpreted the first three axes of the CCA and computed the percent of variation in the biomass data that they explained. We used Monte Carlo tests, with 999 randomizations, to test the significance of the first axis. The significance of the second and third axes were not tested because a simple randomization test for axes 2 and 3 may bias the $p$-values (McCune and Grace 2002). Row and column scores were standardized in the analysis. We constructed ordination diagrams of the first three axes. Taxa linear combination scores for two axes were plotted against each other so that each taxon was a point on the plot. The abiotic factors were plotted as lines radiating out from the center of the ordination scores. The angle of the line shows the direction of maximum change of that abiotic factor across the diagram and the length of the line is proportional to the rate of change. Abiotic factors with longer lines are more strongly related to the pattern of community variation shown in the diagram (ter Braak 1987).

\section{RESULTS}

\section{Abiotic Factors}

River flow and precipitation patterns in central Nebraska were dramatically different between 1999 and 2000. In 1999, average monthly flows in the Platte River ranged from a low of $11.8 \mathrm{~cm}^{3} \mathrm{~s}^{-1}$ above the
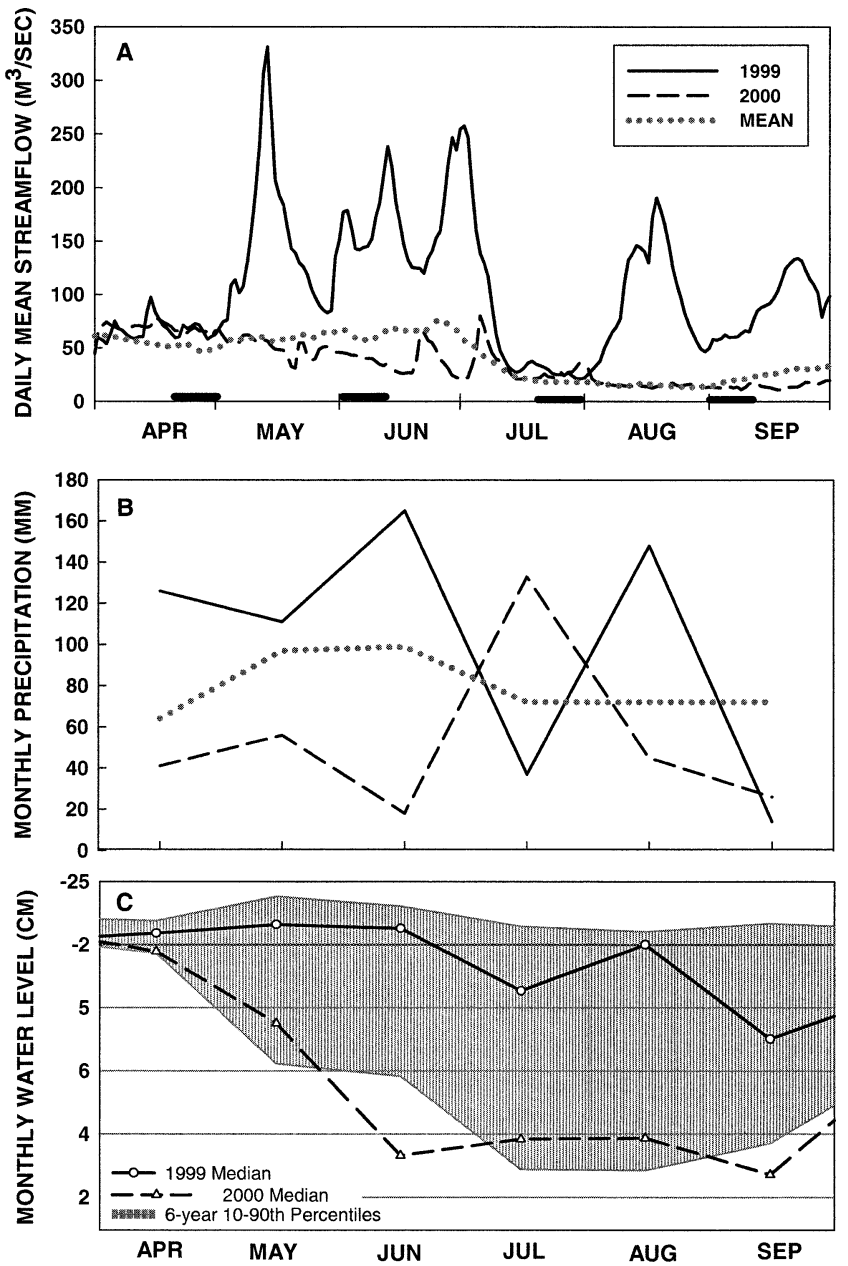

Figure 1. A) Daily mean streamflow in the Platte River at Grand Island, Nebraska for April-September, 1999-2000 and 70-year mean (http://waterdata.usgs.gov/nwis; U.S. Geological Survey Station No. 06770500). Bars on the $\mathrm{X}$-axis of A represent the four sampling periods of the study. B) Monthly precipitation at Grand Island, Nebraska for 1999 and 2000. C) Water-level pattern from a well located in a riparian grassland along the Platte River showing the range of water levels for a 6-year period prior to the study (19901992, 1996-1998) and for two years during the study (1999 and 2000). The 6-year range of water levels excludes $10 \%$ of the highest and lowest mean-daily water levels for each month to show the "typical" range for $80 \%$ of the monthly water levels. Modified from Henszey et al. (2004) with permission.

long-term flows for April to a high of $100.6 \mathrm{~cm}^{3} \mathrm{~s}^{-1}$ above long-term flows for June (NWIS 2003). In contrast, flows in 2000 were much lower than 1999, with flows ranging from a low of $28.1 \mathrm{~m}^{3} \mathrm{~s}^{-1}$ below longterm flows for June to a high of $12.9 \mathrm{~m}^{3} \mathrm{~s}^{-1}$ above long-term flows for April (NWIS 2003). Daily river flows were similar between years during periods 1 and 3 of our study but were higher during periods 2 and 4 in 1999 (Figure 1). Annual precipitation during our 
Table 1. Results of analysis of variance to examine effects of site elevation on soil characteristics of wet meadows along the Platte River in south-central Nebraska, 1999-2000. Values for each variable expressed as LSMEANS. Standard errors (SE) are equivalent for all LSMEANS for that variable. Means sharing the same letter, within row, are not significantly different at a significance level of 0.05 .

\begin{tabular}{|c|c|c|c|c|c|c|c|}
\hline \multirow[b]{2}{*}{ Variable } & \multicolumn{3}{|c|}{ LSMEANS } & \multirow[b]{2}{*}{ SE } & \multirow[b]{2}{*}{$F$} & \multirow[b]{2}{*}{$d f$} & \multirow[b]{2}{*}{$P$} \\
\hline & High & Mid & Low & & & & \\
\hline \multicolumn{8}{|c|}{ Differences among elevations } \\
\hline Potassium (ppm) & $226 \mathrm{a}$ & $193 \mathrm{ab}$ & $150 \mathrm{~b}$ & 20.0 & 3.61 & 2,22 & 0.044 \\
\hline Nitrogen $(\%)$ & $0.18 \mathrm{a}$ & $0.27 \mathrm{ab}$ & $0.35 \mathrm{~b}$ & 0.04 & 7.40 & 2,22 & 0.044 \\
\hline Organic matter $(\%)$ & $3.40 \mathrm{a}$ & $4.48 \mathrm{~b}$ & $5.33 \mathrm{c}$ & 0.38 & 12.65 & 2,22 & $<0.001$ \\
\hline Clay $(\%)$ & $8.7 \mathrm{a}$ & $14.8 \mathrm{~b}$ & $17.6 \mathrm{~b}$ & 1.7 & 10.93 & 2,22 & $<0.001$ \\
\hline Sand $(\%)$ & $68.3 \mathrm{a}$ & $56.6 \mathrm{~b}$ & $56.2 \mathrm{~b}$ & 3.6 & 4.77 & 2,22 & 0.019 \\
\hline Silt $(\%)$ & $23.0 \mathrm{a}$ & $28.5 \mathrm{a}$ & $26.2 \mathrm{a}$ & 2.3 & 1.72 & 2,22 & 0.202 \\
\hline \multicolumn{8}{|c|}{ Interactions between elevation and year } \\
\hline Phosphorus (ppm) & & & & & 6.73 & 2,33 & 0.004 \\
\hline 1999 & $6.80 \mathrm{a}$ & $4.10 \mathrm{~b}$ & $5.45 \mathrm{ab}$ & 0.75 & & & \\
\hline 2000 & $6.58 \mathrm{a}$ & $7.90 \mathrm{ab}$ & $8.82 \mathrm{~b}$ & 0.75 & & & \\
\hline $\mathrm{pH}$ & & & & & 5.91 & 2,33 & 0.006 \\
\hline 1999 & $7.19 \mathrm{a}$ & $7.52 \mathrm{ab}$ & $7.64 \mathrm{~b}$ & 0.16 & & & \\
\hline 2000 & $7.25 \mathrm{a}$ & $8.02 \mathrm{~b}$ & $7.47 \mathrm{a}$ & 0.16 & & & \\
\hline
\end{tabular}

study was $10.9 \mathrm{~cm}$ above normal in 1999 and $15.8 \mathrm{~cm}$ below normal in 2000. Monthly precipitation was above the normal range during April-June and August 1999 but below the normal range during those same periods in 2000 (Figure 1; National Climatic Data Center 2000). As a result of the wet and dry conditions in 1999 and 2000, respectively, ground-water levels in the wet meadows were also much higher in 1999 than 2000 (Figure 1).

Most soil characteristics were significantly affected by elevation $(P<0.05$; Table 1$)$. High elevations (ridges) had the highest levels of sand and $\mathrm{K}$ and the lowest levels of $\mathrm{N}$, organic matter, and clay. Low elevations (sloughs) had the highest levels of $\mathrm{N}$, organic matter, and clay and the lowest levels of sand; however, N, clay, and sand were not significantly different from mid-elevations. Silt did not differ among elevations in the wet meadows. For $\mathrm{pH}$ and $\mathrm{P}$, there was a significant elevation and year interaction. In 1999, $\mathrm{pH}$ was significantly lower in high elevations than low elevations, but $\mathrm{pH}$ for mid-elevations did not differ significantly from either high or low elevations. In 2000, mid-elevations had a significantly higher $\mathrm{pH}$ than low and high elevations; $\mathrm{pH}$ for low and high elevations did not differ significantly from each other. In 1999, $\mathrm{P}$ in high elevations was greater than in midelevations, and $\mathrm{P}$ did not differ significantly between high and low elevations and low and mid-elevations. For 2000, P was greater in low elevations than high elevations but did not significantly differ between high and mid-elevations and low and mid-elevations.

Water-table depth was highly variable during the study, with values ranging from at or just above the surface to $>2 \mathrm{~m}$ below the surface (Table 2). Within periods, water-table depth was most variable during period 1 (coefficient of variation $[\mathrm{CV}]=80 \%$ ) and least variable during periods 3 and $4(\mathrm{CV}=47-49 \%)$. Mean water-table depth decreased over the four periods, with the highest water-table depth (i.e., above or close to the surface) occurring during period 1 and lowest occurring during period 4. Soil moisture showed a similar trend, with the highest mean soil moisture occurring during period $1(41 \%)$ and lowest occurring during period 4 (27\%). Compared to watertable depth, soil moisture levels were less variable within each period ( $\mathrm{CV}$ range $=35-49 \%$ ). Surface and subsurface soil temperatures and root mass also reflected seasonal changes. The lowest temperatures occurred in period 1 and highest temperatures occurred in period 3, while root mass was greatest in period 1 and lowest in period 4. Litter cover, depth, and mass were fairly consistent among periods (Table 2).

\section{Soil Invertebrate Community}

We identified 48 and 50 invertebrate taxa in 1999 and 2000, respectively, with 25 taxa occurring in both years. Of the 73 total taxa found in this study, 39 are considered soil inhabitants (i.e., primarily soil inhabitants during their larval and/or adult life stage). Total invertebrate biomass was primarily composed of six taxa: two earthworms (Aporrectodea trapezoides [Duges] and Diplocardia spp.), Isopoda, Scarabaeidae, and Elateridae (94.5\%), with earthworms and Scarabaeidae accounting for $82.5 \%$ of the total biomass (Table 3 ). We found elevation by period $\left(F_{6,66}=5.26, P<0.001\right)$ 


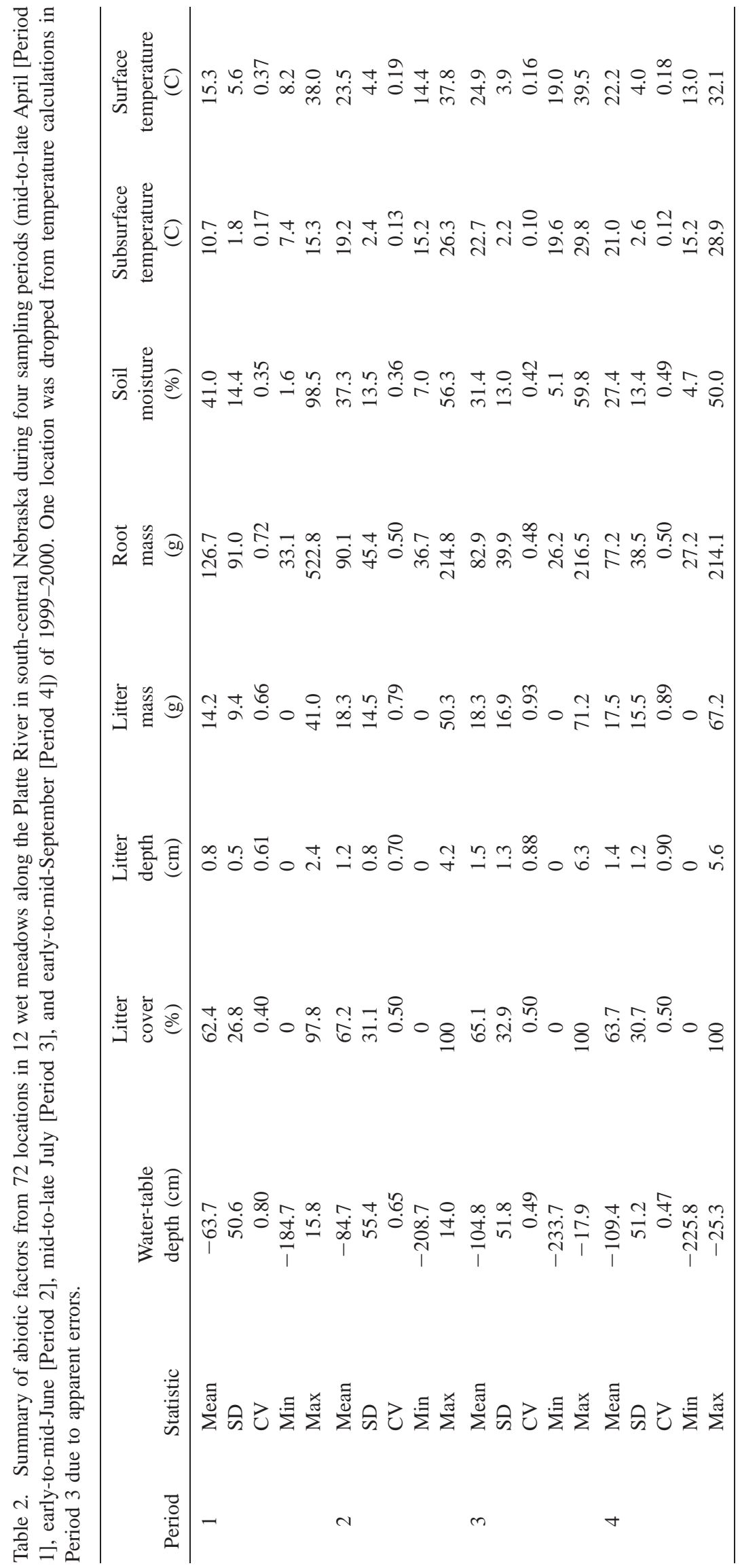


Table 3. Total invertebrate biomass and biomass for the most abundant taxa $\mathrm{g} \mathrm{m}^{-2}$ collected from soil blocks at 72 locations in 12 wet meadows along the Platte River in south-central Nebraska during four sampling periods (mid-to-late April, early-to-midJune, mid-to-late July, and early-to-mid-September), 1999-2000. Values expressed as LSMEANS. Standard errors (SE) are equivalent for all LSMEANS for that variable.

\begin{tabular}{lccc}
\hline \multicolumn{1}{c}{ Taxa } & 1999 & 2000 & \\
& LSMEAN & LSMEAN & SE \\
\hline Aporrectodea trapezoides & 10.864 & 5.776 & 2.237 \\
Scarabeidae & 3.610 & 2.334 & 0.390 \\
Diplocardia spp. & 1.565 & 0.314 & 0.194 \\
Isopoda & 0.444 & 1.334 & 0.234 \\
Elateridae & 0.323 & 0.282 & 0.063 \\
Tipulidae & 0.214 & 0.104 & 0.075 \\
Carabidae & 0.154 & 0.126 & 0.045 \\
Lepidoptera & 0.136 & 0.157 & 0.046 \\
Diplopoda & 0.122 & 0.138 & 0.042 \\
Formididae & 0.083 & 0.104 & 0.032 \\
Curculionidae & 0.036 & 0.108 & 0.058 \\
Lampyridae & 0.018 & 0.051 & 0.012 \\
Staphylinidae & 0.024 & 0.017 & 0.009 \\
Araneida & 0.018 & 0.009 & 0.006 \\
Stratiomyidae & 0.015 & 0.016 & 0.009 \\
Planorbidae & 0.010 & 0 & 0.007 \\
Meloidae & 0.010 & 0.003 & 0.005 \\
Tabanidae & 0.009 & 0.010 & 0.005 \\
Acarina & 0.003 & 0.001 & 0.001 \\
Phalangida & 0.002 & 0.004 & 0.003 \\
Hydrophilidae & 0.001 & 0.001 & 0.001 \\
Total invertebrate & 17.917 & 11.406 & 2.565 \\
\hline
\end{tabular}

and elevation by year $\left(\mathrm{F}_{2,22}=3.43, P=0.05\right)$ interactions for total invertebrate biomass. During period 1 , total invertebrate biomass was greatest for high elevations (LSMEANS $\left.=33.93 \mathrm{~g} \mathrm{~m}^{-2}, \mathrm{SE}=3.48\right)(P$ $<0.022)$ and did not differ significantly between mid$\left(\right.$ LSMEANS $\left.=25.20 \mathrm{~g} \mathrm{~m}^{-2}, \mathrm{SE}=3.48\right)$ and low elevations $\left(\right.$ LSMEANS $\left.=18.13 \mathrm{~g} \mathrm{~m}^{-2}, \mathrm{SE}=3.48\right)(P$ $=0.061)$. Total invertebrate biomass within the other periods did not differ significantly among elevations $(P>0.091)$.

We examined A. trapezoides biomass for effects of elevation within each year and period because we found interactions between period and year, elevation and year, and elevation and period $(F>2.71, P<$ 0.035). In 1999, A. trapezoides biomass differed among elevations during periods 1 and 2 . In period 1 , A. trapezoides biomass was greater in high $\left(\right.$ LSMEANS $\left.=29.49 \mathrm{~g} \mathrm{~m}^{-2}, \mathrm{SE}=3.87\right)$ and mid$\left(\right.$ LSMEANS $\left.=24.48 \mathrm{~g} \mathrm{~m}^{-2}, \mathrm{SE}=3.87\right)$ elevations than in low elevations (LSMEANS $=14.43 \mathrm{~g} \mathrm{~m}^{-2}, \mathrm{SE}$ 3.87) $(P<0.013)$. In period $2, A$. trapezoides biomass was highest in mid-elevations $\left(20.19 \mathrm{~g} \mathrm{~m}^{-2}\right.$, SE = $3.87)$ and lowest in high $\left(11.79 \mathrm{~g} \mathrm{~m}^{-2}, \mathrm{SE}=3.87\right)$ and low $\left(10.13 \mathrm{~g} \mathrm{~m}^{-2}, \mathrm{SE}=3.97\right)$ elevations $(P<0.037)$. In 2000, A. trapezoides biomass did not differ significantly among elevations during each period $(P>$ 0.075).

Diplocardia spp. biomass differed between years $\left(F_{1,11}=25.39, P<0.001\right)$, but we also found an interaction between elevation and period $\left(F_{6,66}=3.18\right.$, $P=0.009)$. Diplocardia spp. biomass was greater in $1999\left(\right.$ LSMEANS $\left.=1.57 \mathrm{~g} \mathrm{~m}^{-2}, \mathrm{SE}=0.19\right)$ than 2000 $\left(\right.$ LSMEANS $\left.=0.31 \mathrm{~g} \mathrm{~m}^{-2}, \mathrm{SE}=0.19\right)$. In period 1 , Diplocardia spp. biomass was greater in high $\left(\right.$ LSMEANS $\left.=2.44 \mathrm{~g} \mathrm{~m}^{-2}, \mathrm{SE}=0.36\right)$ and mid(LSMEANS $=2.53 \mathrm{~g} \mathrm{~m}^{-2}, \mathrm{SE}=0.36$ ) elevations than low elevations (LSMEANS $=0.38 \mathrm{~g} \mathrm{~m}^{-2}, \mathrm{SE}=0.36$ ) $(P<0.001)$. Diplocardia spp. biomass was greater in high elevations (LSMEANS $=1.50 \mathrm{~g} \mathrm{~m}^{-2}, \mathrm{SE}=0.36$ ) than low elevations (LSMEANS $=0.13 \mathrm{~g} \mathrm{~m}^{-2}, \mathrm{SE}=$ $0.36)(P=0.007)$ during period 2 but did not significantly differ between high and mid-elevations $\left(\right.$ LSMEANS $\left.=1.00 \mathrm{~g} \mathrm{~m}^{-2}, \mathrm{SE}=0.36\right)$ and mid- and low elevations $(P>0.08)$. Diplocardia spp. biomass did not differ significantly among elevations for periods 3 and $4(P \geq 0.215)$.

Scarabaeidae biomass was greater in 1999 $\left(\right.$ LSMEANS $\left.=3.61 \mathrm{~g} \mathrm{~m}^{-2}, \mathrm{SE}=0.39\right)$ than in 2000 $\left(\right.$ LSMEANS $\left.=2.33 \mathrm{~g} \mathrm{~m}^{-2}, \mathrm{SE}=0.39\right)\left(F_{1,11}=7.63\right.$, $P=0.018)$. Scarabaeidae biomass also differed among elevations $\left(F_{3,33}=5.97, P=0.008\right)$; Scarabaeidae biomass was greater in high elevations (LSMEANS = $4.22 \mathrm{~g} \mathrm{~m}^{-2}, \mathrm{SE}=0.53$ ) than mid- (LSMEANS $=3.04$ $\left.\mathrm{g} \mathrm{m}^{-2}, \mathrm{SE}=0.53\right)$ and low elevations (LSMEANS $=$ $\left.3.04, \mathrm{~g} \mathrm{~m}^{-2}, \mathrm{SE}=0.53\right)(P \leq 0.005)$.

Isopoda biomass was greater in $2000\left(1.33 \mathrm{~g} \mathrm{~m}^{-2}\right.$, $\mathrm{SE}=0.23)$ than $1999\left(0.44 \mathrm{~g} \mathrm{~m}^{-2}, \mathrm{SE}=0.23\right)\left(F_{1,11}\right.$ $=10.78, P=0.007)$ and was influenced by elevation $\left(F_{2,22}=3.79, P=0.038\right)$. Isopoda biomass was greater in low elevations (LSMEANS $=1.32 \mathrm{~g} \mathrm{~m}^{-2}, \mathrm{SE}=$ 0.28 ) than high elevations (LSMEANS $=0.35 \mathrm{~g} \mathrm{~m}^{-2}$, $\mathrm{SE}=0.28)(P=0.013)$, but their biomass for low and high elevations was not significantly different from mid-elevations (LSMEANS $=0.99 \mathrm{~g} \mathrm{~m}^{-2}, \mathrm{SE}=$ $0.28)(P>0.09)$. Diplopoda and Lepidoptera biomass were influenced by elevation (Diplopoda: $F_{2,22}=5.64$, $P=0.01$; Lepidoptera: $\left.F_{2,22}=3.61, P=0.044\right)$. Diplopoda biomass was significantly greater in high $\left(\right.$ LSMEANS $\left.=0.20 \mathrm{~g} \mathrm{~m}^{-2}, \mathrm{SE}=0.04\right)$ and mid$\left(\right.$ LSMEANS $\left.=0.15 \mathrm{~g} \mathrm{~m}^{-2}, \mathrm{SE}=0.04\right)$ elevations than in low elevations (LSMEANS $=0.03 \mathrm{~g} \mathrm{~m}^{-2}, \mathrm{SE}=$ 0.04) $(P \leq 0.031)$. Lepidoptera biomass was significantly greater in high elevations (LSMEANS $=0.22$ $\left.\mathrm{g} \mathrm{m}^{-2}, \mathrm{SE}=0.05\right)$ than low elevations (LSMEANS $=$ $\left.0.04 \mathrm{~g} \mathrm{~m}^{-2}, \mathrm{SE}=0.05\right)(P=0.016)$ and did not significantly differ between high and mid-elevations $\left(\right.$ LSMEANS $\left.=0.17 \mathrm{~g} \mathrm{~m}^{-2}, \mathrm{SE}=0.05\right)$ and low and mid-elevations $(P>0.07)$. We found an interaction 
between elevation and period for Tipulidae biomass $\left(F_{6,66}=2.99, P=0.012\right)$. During periods 2 and 3 , Tipulidae biomass was greater in low elevations (period 2: LSMEANS $=0.73 \mathrm{~g} \mathrm{~m}^{-2}, \mathrm{SE}=0.14$; period 3: LSMEANS $\left.=0.72 \mathrm{~g} \mathrm{~m}^{-2}, \mathrm{SE}=0.13\right)$ than in midand high elevations (LSMEANS $\leq 0.01 \mathrm{~g} \mathrm{~m}^{-2}, \mathrm{SE}=$ $0.13)(P=0.0003)$. During periods 1 and 4 , Tipulidae biomass did not differ significantly among elevations $(P>0.141)$.

Relationship of Soil Invertebrate Community to Abiotic Factors

Period 1. We included 18 invertebrate taxa (i.e., only those that occurred in $\geq 5 \%$ of the locations) from 72 locations in the CCA. The sum of the 3 eigenvalues was 0.253 , and total variance was 1.518 . The first and second CCA axes of the ordination explained $10.7 \%$ and $3.1 \%$ of variation, respectively. Results of the Monte-Carlo test showed that the first CCA axis explained more variation in invertebrate biomass than expected by chance $(P=0.001)$. The species-environment correlation coefficients for the first and second CCA axes were 0.810 and 0.532 , respectively, suggesting a strong relation between invertebrate taxa and abiotic factors for the first CCA axis. Of the 15 abiotic factors, soil moisture, water-table depth, $\mathrm{pH}$, and clay had the highest correlation coefficients (all positive) with the first CCA axis (Table 4). P and subsurface temperature were most strongly correlated with the second CCA axis, with $\mathrm{P}$ negatively correlated and subsurface temperature positively correlated with the axis.

The first CCA axis seems to represent a soil wetness and alkalinity gradient that is associated with elevation. Taxa highly associated with the wetter, alkaline soils (i.e., high positive scores along the first CCA axis) were Tipulidae, Staphylinidae, Tabanidae, Acarina, and Isopoda, whereas taxa highly associated with drier, less alkaline soils (i.e., high negative scores along the first CCA axis) were Curculionidae, Scarabaeidae, and Diplopoda (Figure 2). The second CCA axis appears to represent an elevation gradient of increasing subsurface temperatures and decreasing $\mathrm{P}$ levels. Taxa associated with the warmer conditions were Carabidae, Acarina, and Meloidae, whereas taxa associated with the cooler conditions were Tipulidae and Tabanidae (Figure 2). Taxa intermediate in their relationship to the first and second axes were A. trapezoides, Diplocardia spp., Lepidoptera, and Lampyridae.

Period 2. We included 15 invertebrate taxa from 70 locations in the CCA. The sum of the 3 eigenvalues was 0.310 , and total variance was 1.499 . The first two CCA axes of the ordination accounted for $16.3 \%$ of

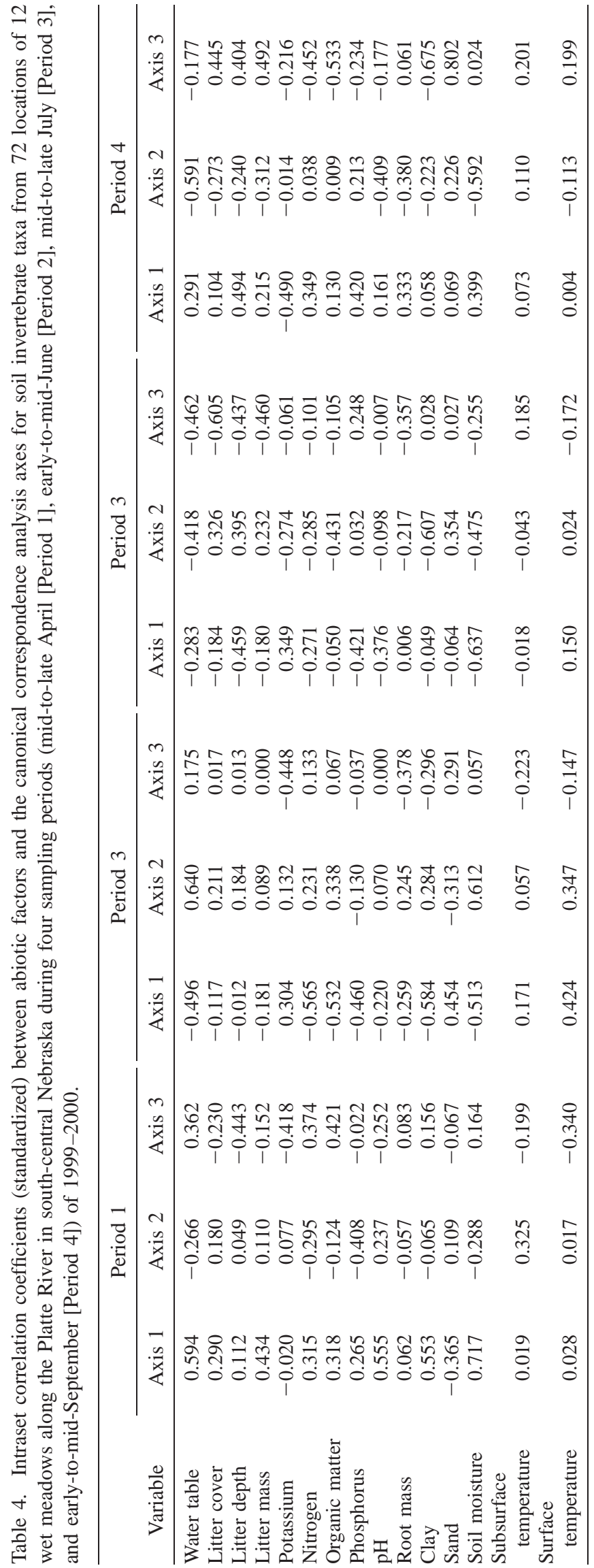




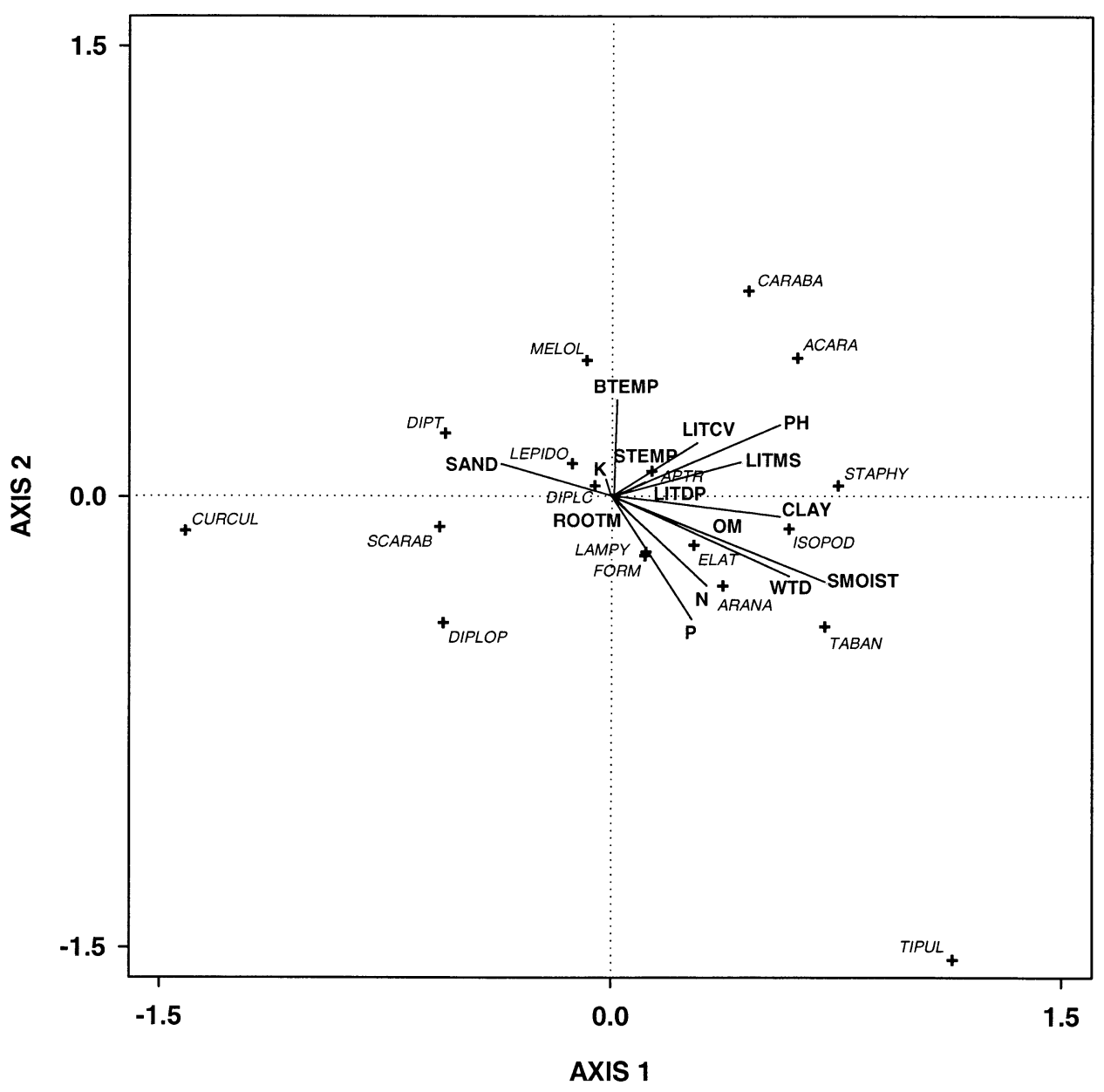

Figure 2. Biplot of first and second CCA axes for soil invertebrate taxa in wet meadows along the central Platte River during mid-to-late April (A), early to mid-June (B), mid-to-late July (C), and early-to-mid-September (D), 1999-2000. Axes are scaled by standard deviates. Invertebrate taxa shown are Curculionidae (CURCUL), Diptera (DIPT), Scarabaeidae (SCARAB), Diplocardia spp. (DIPLC), Lampyridae (LAMPY), Formicidae (FORM), Lepidoptera (LEPIDO), Meloidae (MELOL), Aporrectodea trapezoides (APTR), Carabidae (CARAB), Acarina (ACARA), Staphylinidae (STAPHY), Elateridae (ELAT), Isopoda (ISOPOD), Diplopoda (DIPLOP), Aranaeida (ARANA), Tabanidae (TABAN), and Tipulidae (TIPUL). The abiotic factors are sand, root mass (ROOTM), potassium (K), subsurface temperature (BTEMP), litter cover (LITCV), litter mass (LTMS), pH, nitrogen $(\mathrm{N})$, phosphorus (P), water-table depth (WTD), soil moisture (SMOIST), clay, organic matter (OM), litter depth (LITDP), and surface temperature (STEMP).

the variation in invertebrate biomass, with the first and second CCA axes explaining $8.7 \%$ and $7.6 \%$ of the variation, respectively. According to the Monte-Carlo test, the first CCA axis explained more variation in the invertebrate biomass than expected by chance $(P=$ 0.007). The species-environment correlation coefficients for the first and second CCA axes were 0.730 and 0.688 , respectively. Abiotic factors most correlated (all negatively) with the first CCA axis were clay, $\mathrm{N}$, organic matter, soil moisture, and water-table depth, while abiotic factors most correlated with the second CCA axis were water-table depth and soil moisture (both positively) (Table 4).

The first CCA axis seems to represent a gradient of increasing soil dryness and sand and decreasing soil fertility (Figure 3). Taxa with the highest positive scores along the first CCA axis were Diplopoda, Diplocardia spp., Curculionidae, and Carabidae, whereas taxa with the highest negative scores along the first CCA axis were Tipulidae, Araneida, and Isopoda. For the second CCA axis, the gradient is characterized by increasing soil wetness. Tipulidae were most associated with the wetter conditions, whereas Curculionidae were strongly related and Scarabaeidae were moderately related to the drier conditions (Figure 3 ).

Period 3. We included 14 invertebrate taxa from 70 locations for the CCA analysis. The sum of the 3 eigenvalues was 0.368 , and total variance was 1.954 . The first three CCA axes explained $18.8 \%$ of the total 


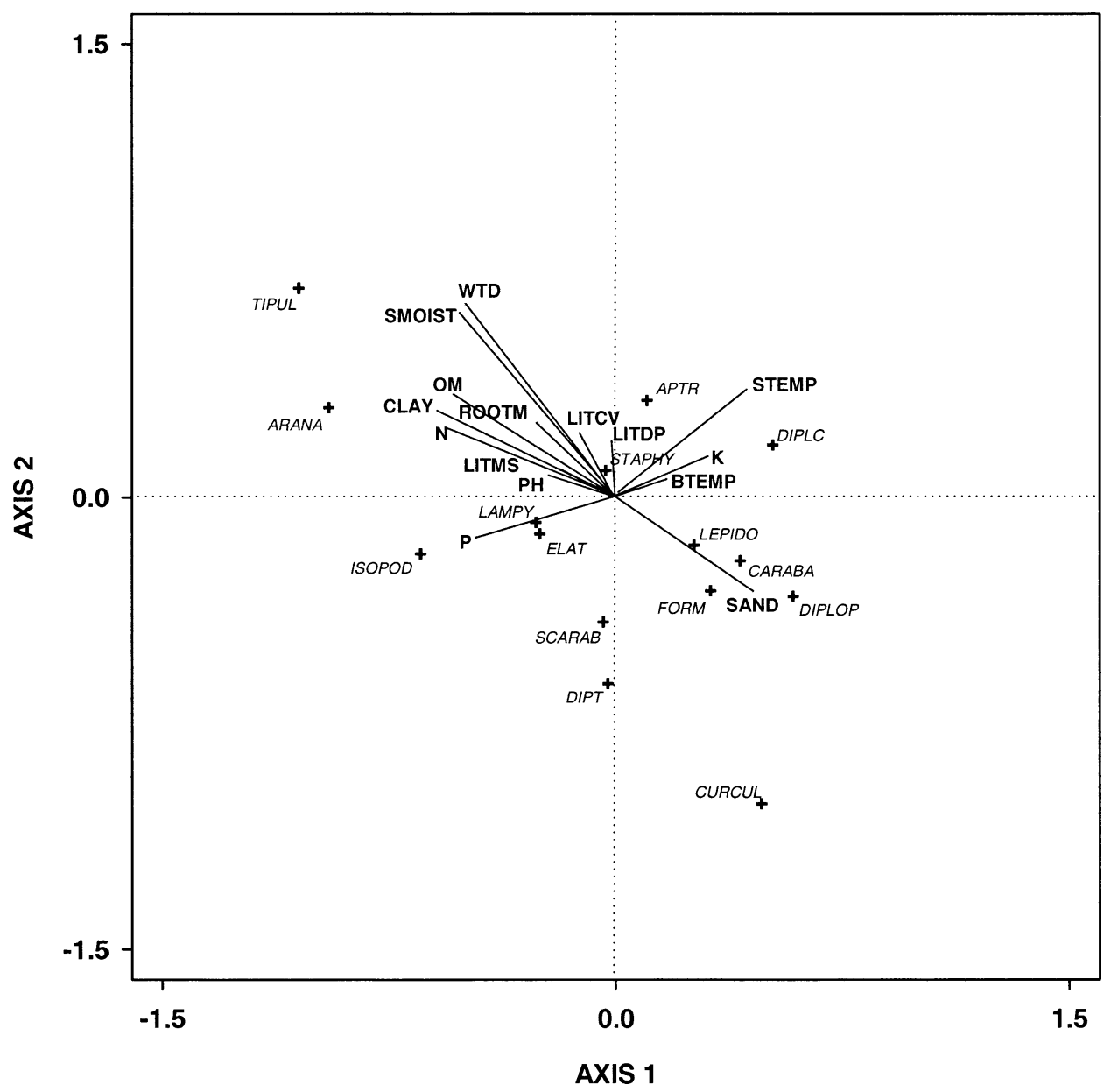

Figure 2. Continued.

variation in invertebrate biomass, with the first and second CCA axes explaining $8.4 \%$ and $5.9 \%$ of the variation. The Monte-Carlo test showed that the first axis explained significantly more variation in the biomass than expected by chance $(P=0.022)$. The species-environment correlation coefficients for the first and second CCA axes were 0.772 and 0.674 , respectively. Soil moisture and litter depth were most correlated (both negatively) with the first CCA axis, and clay and soil moisture were most correlated (both negatively) with the second CCA axis (Table 4).

The first CCA axis seems to describe a gradient of wetter, more alkaline sites with greater amounts of litter and $\mathrm{P}$ to drier, less alkaline sites with lesser amounts of litter and P. Scarabaeidae, Diplopoda, Diplocardia spp., Formicidae, and Lepidoptera were highly associated with the drier, less alkaline sites, and Isopoda, Staphylinidae, and Tipulidae were highly associated with the wetter, more alkaline sites (Figure 4). The second CCA axis also suggests a gradient of decreasing wetness but also decreasing clay and organic matter. Diplopoda and Lepidoptera had the highest positive scores associated with the second CCA axis, whereas Tipulidae, Carabidae, and Acarina had the highest negative scores associated with the second CCA axis (Figure 4).

Period 4. We included 16 invertebrate taxa from 72 locations for the CCA analysis. The sum of the 3 eigenvalues was 0.371 , and total variance was 1.846 . The three CCA axes of the ordination explained $20.1 \%$ of the total invertebrate biomass variation. The first and second CCA axes accounted for $8.2 \%$ and $7.6 \%$ of the explained variation. Results from the MonteCarlo test showed that the first CCA axis explained more variation in the invertebrate biomass than expected by chance $(P=0.009)$. The species-environment correlation coefficients for the first and second CCA axes were 0.751 and 0.777 , respectively. Litter depth, K, P, and soil moisture were the most correlated variables with the first CCA axis; litter depth, $\mathrm{P}$, and soil moisture were positively correlated and $\mathrm{K}$ was negatively correlated (Table 4). The abiotic factors most correlated (all negative) with the second CCA axis were soil moisture, water-table depth, and $\mathrm{pH}$.

The first CCA axis describes a vegetation biomass 


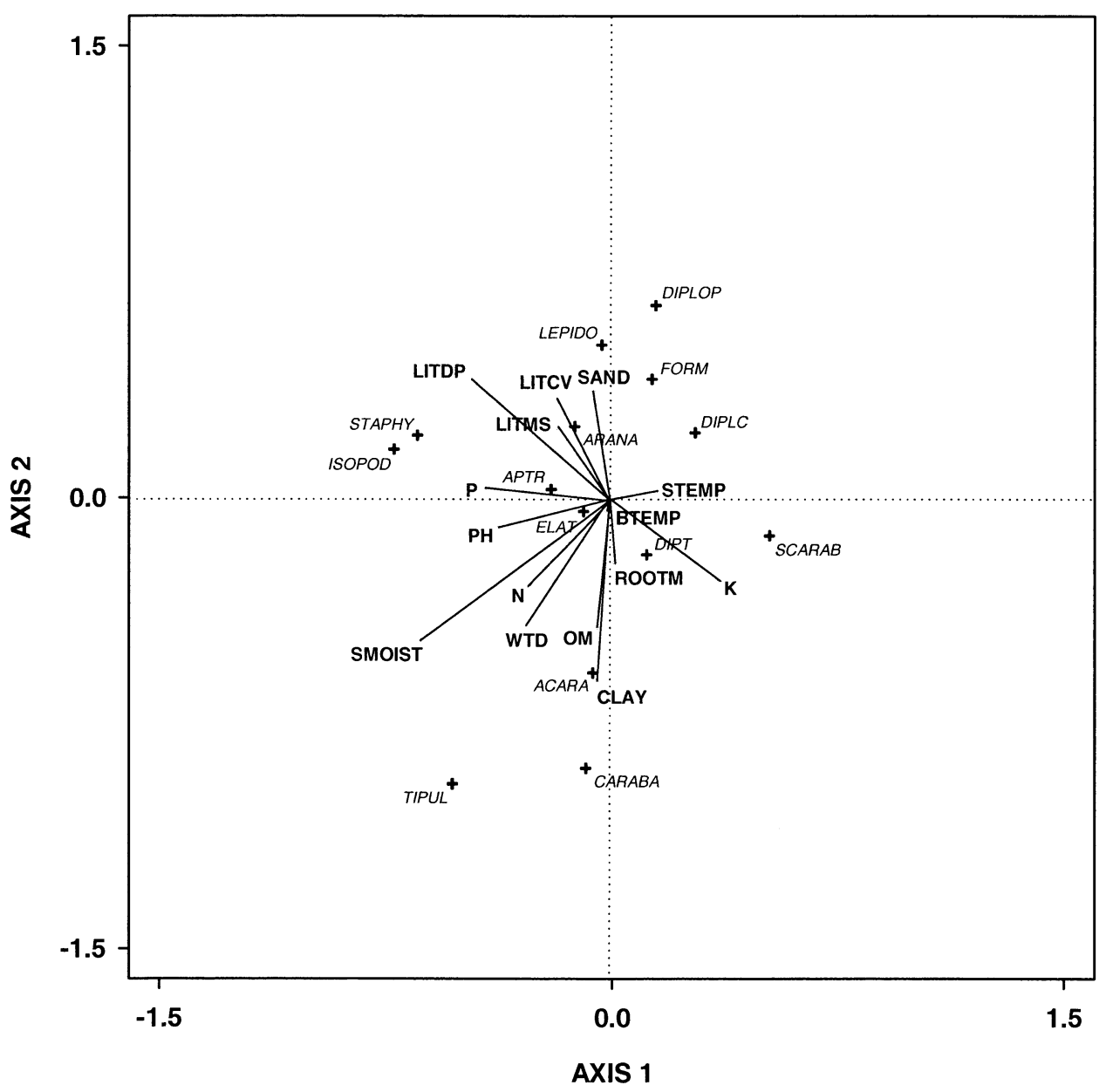

Figure 2. Continued.

gradient from sites with small amounts of litter, roots, and nutrients ( $\mathrm{P}$ and $\mathrm{N}$ ) to sites with large amounts of litter, roots, and nutrients. Araneida and Isopoda had the highest positive scores along the first CCA axis, and Lepidoptera and Diplocarda spp. had the highest negative scores (Figure 5). The second CCA axis suggests a gradient of wetter, high alkaline soils with large vegetation biomass (litter and roots) to drier, lower alkaline soils with small vegetation biomass. Lepidoptera had the highest positive score along the second CCA axis, whereas Tipulidae, Diplocardia spp., Elateridae, and Araneida had the highest negative scores (Figure 5).

\section{DISCUSSION}

\section{Soil Invertebrate Community}

Soil invertebrate communities in grasslands are quite diverse, encompassing microfauna (protozoa), mesofauna (nematodes, enchytraeids, and microarthropods), and macrofauna (macroarthropods and earthworms) (Stanton 1988, Curry 1994, Ransom et al.
1998). Although we only collected macrofauna, the soil invertebrate community in wet meadows along the Platte River appears to be diverse. The richness of the soil invertebrate community in these meadows is related to the unique environmental conditions created by the interaction of the ridge-swale complexes and hydrology. For example, ridge tops are characterized by drier conditions with low organic matter, high amounts of sand, and low root biomass, while swales are characterized by wetter conditions with high organic matter, clay, and root biomass. Consequently, these ridge-swale complexes create a high degree of spatial variability in abiotic factors that result in a diverse array of microhabitats for a variety of soil invertebrates.

Earthworms typically constitute the majority of the biomass in soil invertebrate communities in tallgrass prairie ecosystems (Seastedt et al. 1987, Ransom et al. 1998). In riparian grasslands in Nebraska, earthworms constituted $70-80 \%$ of the total soil invertebrate biomass (Nagel and Harding 1987, Davis and Vohs 1993). In our study, earthworm biomass accounted for 


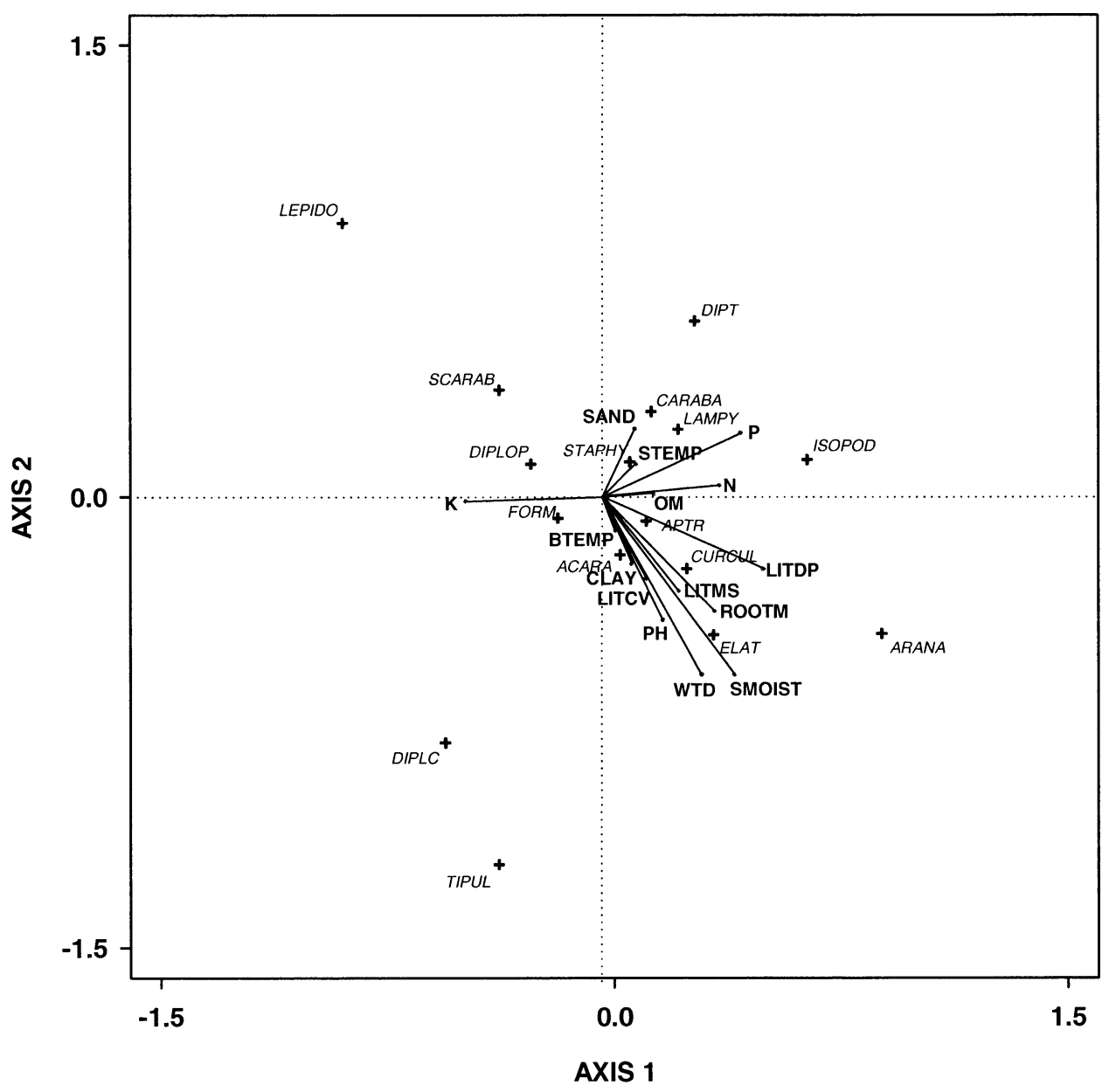

Figure 2. Continued.

$64 \%$ of the total soil invertebrate biomass. Earthworm biomass in wet meadows was considerably greater (12.4 $\mathrm{g} \mathrm{m}^{-2}$ in our study and $13.1 \mathrm{~g} \mathrm{~m}^{-2}$ in Nagel and Harding 1987) than in a tallgrass prairie in Kansas (0.2-0.8 $\mathrm{g} \mathrm{m}^{-2}$ [Callaham et al. 2003] and $6.0 \mathrm{~g} \mathrm{~m}^{-2}$ [Seastedt et al. 1987]). Greater earthworm biomass in subirrigated wet meadows may be related to favorable moisture conditions. Peterson (1982) noted that earthworms achieve high standing crop in mesic grasslands, especially those with high soil organic matter. Interestingly, a major component of the earthworm fauna is an introduced European species, A. trapezoides. Aporrectodea trapezoides accounted for $91 \%$ of the earthworm biomass, while native earthworm taxa, Diplocardia spp., accounted for $9 \%$ of the biomass. Hendrix and Bohlen (2002) raised serious concerns about the impacts of exotic earthworms on North American ecosystems. Currently, little is known about the impact of A. trapezoides on Diplocardia spp. and other native soil fauna nor its impact on soil processes and plant communities in wet meadows.

The dominant macroarthropod taxon in wet meadows was Scarabaeidae, which accounted for $60 \%$ of the total macroarthropod biomass. Similarly, Davis and Vohs (1993) reported that Scarabaeidae accounted for $73 \%$ of the macroarthropod biomass in riparian grasslands in Nebraska. In a tallgrass prairie in Kansas, Scarabaeidae accounted for nearly $79 \%$ of the macroarthropod biomass on annually burned sites but accounted for only $48 \%$ of the biomass on unburned sites (Seastedt 1984). Seastedt (1984) attributed the greater proportion of Scarabaeidae, which feed on roots during the larval stage, to an increase in belowground plant production in response to burning. In our study, the large abundance of Scarabaeidae may be related to increased belowground production due to periodic burning (every 3-4 years) of the meadows, as well as the more optimal moisture conditions created by high ground-water levels in the meadows during portions of the growing season.

\section{Annual and Seasonal Variation}

River flow and precipitation patterns differed dramatically between the two years of our study. In 1999, river flows and precipitation were above normal, 
whereas river flows and precipitation in 2000 were below normal. The response to drought in our study was highly variable among soil invertebrate taxa. For example, A. trapezoides, Diplocardia spp., and Scarabaeidae showed reductions in biomass of $47 \%, 80 \%$, and $35 \%$, respectively, from 1999 to 2000, while Isopoda biomass increased by $202 \%$. Similarly, Todd (1996) reported that herbivorous nematodes showed reductions in biomass of 55-67\% during drought periods, while microbivorous nematodes showed reductions of $8-38 \%$.

Drought conditions likely affected the two earthworm taxa and Scarabaeidae differently. The reduction in earthworm biomass may have been caused by them retreating deeper into the soil profile (beyond the 20$\mathrm{cm}$ collection depth) where moisture conditions were more favorable (Gerard 1967, Curry 1998). However, earthworm survival and fecundity, which are strongly influenced by soil moisture, may have also been affected by the drought (Edwards and Lofty 1977, Curry 1998). In particular, Diplocardia spp. may have experienced greater mortality than $A$. trapezoides because they typically inhabit the dense root zone of the upper $10 \mathrm{~cm}$ of the soil and generally do not retreat to great depths $(>30 \mathrm{~cm})$ during drought (James 1982). In contrast, Scarabaeidae appear to tolerate low soil moisture levels (10-20\%) without a significant reduction in their activity and growth (Davidson and Roberts 1968). Davis (1991) reported that the greatest biomass for Scarabaeidae in riparian grasslands in $\mathrm{Ne}$ braska occurred at soil moistures of 5-10\%. However, Scarabaeidae biomass appears to be influenced by root biomass and nitrogen concentrations of roots (Seastedt et al. 1986). Seasonal droughts can significantly reduce root production (Hayes and Seastedt 1987). Root mass in the wet meadows of our study decreased by nearly $40 \%$ from 1999 to 2000 . Therefore, the reduction in Scarabaeidae biomass may be more related to decreasing belowground plant production than directly to unfavorable soil moistures. The increase in Isopoda biomass during the drought is difficult to explain since they are generally highly susceptible to water-loss and are restricted to moist environments. However, Warburg (1987) noted that there are some species of Isopoda that " prefer', drier microhabitats. In fact, Aramadillidium vulgare [Latr.], a common isopod species in wet meadows, appears to be rather drought-resistant, with large numbers commonly observed during dry conditions (W. W. Hoback, University of Nebraska at Kearney, personal communication).

Abiotic factors in wet meadows changed throughout the growing season. During our study, soil moisture and water-table depth decreased by $33 \%$ and $72 \%$, respectively, from mid-April to early September, and soil temperature increased by nearly $100 \%$ from mid-
April to early September. Most of the soil arthropods appeared to be unaffected by seasonal changes in abiotic factors, except earthworms. Diplocardia spp. declined by as much of $70 \%$ from mid-April to early September, and A. trapezoides declined by nearly $80 \%$. The decrease in soil moistures throughout the growing season likely played a major role in the decrease in earthworm biomass from mid-April to early September.

The apparent lack of seasonal differences in biomass for many of the soil arthropods may be due to identifying taxa at a coarse taxonomic level (i.e., order or family level). Life cycles and timing of adult emergences often vary among species within an arthropod family. Although the univoltine life cycle is common in many families (e.g., Carabidae, Staphylinidae, and Scarabaeidae), the length of the larval stage is highly variable and can range from 1 to 5 years (Ratcliffe 1991, Curry 1994). For example, life cycles in Elateridae may be 1, 2 or 3 years in length, while carabid species can range from an annual life cycle that includes 2-3 generations/year to having a single 4-year life cycle (Curry 1994). Such variability within families may have masked any seasonal, species-specific changes in biomass.

\section{Influence of Topography}

Several soil invertebrate taxa appeared to be affected by the topographic gradient created by the ridgeswale complexes. We found that biomasses of Scarabaeidae, Diplopoda, and Lepidoptera were greatest in high elevations, whereas biomasses of Tipulidae and Isopoda were greatest in the low elevations. In the case of earthworms, the effect of topographic gradient on their biomass was quite variable depending on the year and period; however, they generally had greater biomasses in the high and mid-elevations. Wet meadows along the Platte River show a strong topographic gradient from low elevation swales to high elevation ridges, which is often a change in relative elevation of $\sim 200 \mathrm{~cm}$ (Henszey et al. 2004). Because of the close proximity of the wet meadows to the river, soil invertebrate communities are likely influenced by fluctuating ground-water levels created by changing river stages throughout the year. Studies of soil arthropods and earthworms in a tallgrass prairie of Kansas have shown a stratification of these taxa along a topographic gradient (Risser et al. 1981, James 1982, Seastedt 1984, Ransom et al. 1998).

Soil moisture conditions, in particular, appear to play a major role in influencing the topographic distributions and abundances of soil invertebrates in the wet meadows. Mean soil moisture levels for high and mid elevations ranged from 22 to $33 \%$, while the mean 
soil moisture level for low elevations was $47 \%$ (C. A. Davis and J. E. Austin, unpublished data). Taxa inhabiting the high elevation sites probably are not as tolerant of greater soil moistures as those taxa inhabiting the low elevation sites. For example, Davis and Vohs (1993) suggested that Scarabaeidae distributions in riparian grasslands along the Platte River were restricted by high soil moistures and that the optimal soil moisture for Scarabaeidae was $<20 \%$. Similarly, earthworm distributions in wet meadows appeared to be limited by high soil moisture levels (at least during certain times of the year); however, unlike Scarabaeidae, they are likely much more tolerant of a wider range of soil moisture levels (Lee 1985). In contrast, Tipulidae and Isopoda, which prefer wet soil conditions (Paris 1963, McCracken et al. 1995), appeared to be restricted by low soil moisture levels in the meadows.

Overall, CCA results indicated that the most important abiotic factors influencing soil invertebrate biomass were soil moisture, water-table depth, litter, soil nutrients (organic matter, N, P, and K), and soil texture (clay and sand). However, the variation explained by the CCA axes was low $(<20 \%)$. This could partly be attributed to other explanatory variables (e.g., land use practices, food quality and quantity, biological interactions, and scale-specific factors) that were not considered in our analysis. A closer examination of abiotic factors suggests water-table depth and soil moisture as the driving forces for most of the soil invertebrate taxa inhabiting wet meadows. These two factors directly influence soil invertebrate distributions by creating favorable moisture conditions and indirectly through their effect on ecosystem processes (e.g., belowground productivity, decomposition, and nutrient cycling) and its interaction with soil properties (Blair et al. 1998, Ransom et al. 1998, Rice et al. 1998). In wet meadows, the influence of these two factors on soil invertebrates likely is more pronounced than other grasslands because of the topographic variability and hydrologic link of the meadows to river stage that result in a wide gradient of soil moistures ranging from saturated soils in the sloughs to drier soils on the ridge tops.

Some of the soil invertebrate taxa seemed to be associated with similar abiotic conditions across periods, while other taxa were highly variable in their associations. Taxa that appeared to remain unchanged in their response to changes in abiotic conditions throughout the season included Tipulidae, Scarabaeidae, and Curculionidae. Tipulidae were always associated with wetter locations with more litter or organic matter and higher alkalinity (i.e., low elevation sloughs), while Curculionidae and Scarabaeidae were always associated with drier, often sandier soils with less organic matter and soil fertility (i.e., high elevation ridges). In contrast, Carabidae and Lepidoptera were quite variable in their associations. Carabidae appeared to be associated with drier, sandy sites during periods 2 and 4 and wetter, clayey sites during period 3. Lepidoptera appeared to have a minimal response to abiotic factors during period 1 , but in periods $2-4$, Lepidoptera appeared to be associated with drier, sandy sites. For some of the taxa, the seasonal change in their association with abiotic factors may be due to the coarse taxonomic resolution used in this study. Because the life-history strategies and habitat selection patterns of genera and species within orders and families may differ considerably, a finer resolution to the species level may have allowed for a clearer interpretation of the patterns we observed.

\section{Conservation Implications}

Wet meadows along the Platte River provide important feeding and nesting habitat to a myriad of migratory and non-migratory birds in the Central Flyway. In particular, these wet meadows are critically important to staging sandhill cranes (Grus canadensis, L.) during the spring (Krapu et al. 1984, Davis 2003). Sandhill cranes rely on these wet meadows to forage for important invertebrate foods (e.g., earthworms, Scarabaeidae, and snails), which contain proteins and calcium that cannot be obtained elsewhere in the Platte River valley (Reinecke and Krapu 1986). Only about $25 \%$ of original native wet meadows remain along the Platte River, and many of these are highly degraded and fragmented (Sidle et al. 1989). Moreover, most of these remaining wet meadows have altered hydrologic regimes due to the reduction in annual flows in the Platte River for hydroelectric and agricultural purposes (Hurr 1983, Wesche et al. 1994). The biotic communities associated with wet meadows, as well as the ecological processes that maintain the meadows, are threatened or at risk from these altered hydrologic regimes (Jelinski and Currier 1996, Whiles et al. 1999, Henszey et al. 2004). In our study, we found that these remaining wet meadows contain diverse soil invertebrate communities that are influenced by soil moisture levels. Because moisture levels are considered to be the driving factor for most wetland and riparian ecosystems (Hall and Harcombe 1998, Henszey et al. 2004), soil invertebrate communities in the wet meadows are particularly vulnerable to altered hydrologic regimes. Although the long-term impacts of changes in hydrologic patterns on wet meadow soil invertebrates are largely unknown, shifts in soil invertebrate distribution patterns along the topographic gradient (i.e., distributional patterns shifting downward to more favorable moisture regimes) and possibly complete 
elimination of more moisture-tolerant taxa could be expected. Conservationists should be concerned about the potential long-term impacts of changes in the composition and distribution patterns of the wet meadow soil invertebrate community on the ecological processes important for maintaining the biological integrity of these systems.

The hydrology of Platte River wet meadows is a complex interaction between surface- and ground-water levels and river stage, evapotranspiration, and precipitation (Hurr 1983, Wesche et al. 1994). However, management of river flows may be a feasible option for maintaining and enhancing the biotic communities in wet meadows. Henszey et al. (2004) suggested that ground-water levels in wet meadows could potentially be managed through appropriate in-stream releases from storage reservoirs on tributaries of the Platte River. Currently, flow requirements for maintaining wet meadows are not well-defined or known, but river-flow management should focus on regaining as much as possible of the former hydrograph through properly timed high quantity flows that provide a proper hydrologic regime for wet meadows (National Research Council 2004). Future research efforts need to focus on models linking the flows and ground-water levels to the biotic communities of the wet meadows.

A critical component of habitat management in the Platte River Ecosystem is restoration of wet meadows. Specifically, the conversion of low-lying, marginal agricultural land should be a high priority. During the last 20 years, several wet meadow restoration techniques have been employed with limited success because information about the relationships between the physical environment and biotic communities was lacking (Pfeiffer 1999). Henszey et al. (2004) found that ground-water levels played a major role in influencing the distribution and abundance of plant communities in wet meadows. Similarly, our results indicated that ground-water levels likely play a major role in the distribution and abundance of soil invertebrate communities. Although it is difficult to replicate the ecological processes and functions of native wet meadows completely, future restorations must be designed to include the natural topography (i.e., ridge-swale complexes) and hydrology. Because most agricultural lands along the Platte River have been leveled (i.e., ridge-swale complexes have been removed), the success of these restorations will hinge on whether the natural hydrology, a key factor in wet meadow development, as well as natural topography can be restored.

Results from our study may prove helpful in the development of bioindicators for assessing wet meadow restorations. The usefulness of bioindicators depends on the strength of the relationship between abiotic factors and the community (van Straalen 1997).
Therefore, the development of soil invertebrate bioindicators for wet meadow restorations must include invertebrate taxa that thrive across a wide range of environmental conditions and microhabitats. For example, Tipulidae could be used as an indicator of slough habitat quality, while Scarabaeidae could be used as an indicator of ridge habitat quality. Although we recommend using soil invertebrates as bioindicators for wet meadow restorations, we also recognize limitations. First, depending on the taxa, poor taxonomic resolution may hamper use of certain soil invertebrates as bioindicators. Considerably more research needs to be conducted to refine connections between many of these invertebrates, especially at the genus or species level, and abiotic factors. Second, invertebrate colonization rates can be influenced by the age of restorations (Jansen 1997), so any use of soil invertebrates as bioindicators must also consider the age of the restoration. Finally, other factors such as previous landuse practices of agricultural lands prior to restoration (e.g., spraying of pesticides, and intensive tilling), surrounding land-use practices, and poor establishment of diverse plant communities in the restorations may affect establishment and structure of soil invertebrate communities.

\section{ACKNOWLEDGMENTS}

We thank Scott Demers, Brook Herman, Rhett Johnson, Margaret Kearns, Jaime Kirby, Chris Mettenbrink, Rebecca Presgraves, and Stanley Proboszcz for assistance with both field sampling and laboratory analyses. We also thank the Platte River office of The Nature Conservancy, National Audubon's Lillian Annette Rowe Sanctuary, and Platte River Whooping Crane Trust for allowing access to their lands. Wesley Newton provided invaluable assistance with experimental design and statistical analyses. Michael Palmer assisted with interpretation of CCA. Matt Whiles, Wyatt Hoback, Terry Shaffer, Diane Larson, and two anonymous reviewers provided helpful comments on earlier drafts of the manuscript. Research was supported by U.S. Geologic Survey, Department of Interior, under USGS Agreement No. 98CRAG1010. This work is dedicated to the memory of Paul Currier, a passionate advocate for the Platte River for over 20 years, who sadly passed away in 2003 .

\section{LITERATURE CITED}

Blair, J. M., T. R. Seastedt, C. W. Rice, and R. A. Ramundo. 1998. Terrestrial nutrient cycling in tallgrass prairie. p. 222-243. In A. K. Knapp, J. M. Briggs, D. C. Hartnett, and S. L. Collins (eds.) Grassland Dynamics: Long-term Ecological Research in Tallgrass Prairie. Oxford University Press, Inc., New York, NY, USA.

Blair, J. M., T. C. Todd, and M. A. Callaham, Jr. 2000. Responses 
of grassland soil invertebrates to natural and anthropogenic disturbances. p. 43-71. In D. C. Coleman and P. F. Hendrix (eds.) Invertebrates as Webmasters in Ecosystems. CABI Publishing, New York, NY, USA.

Brown, V. K. and A. C. Gange. 1990. Insect herbivory below ground. Advances in Ecological Research 20:1-58.

Callaham, Jr., M. A., J. M. Blair, T. C. Todd, D. J. Kitchen, and M. R. Whiles. 2003. Macroinvertebrates in North American tallgrass prairie soils: effects of fire, mowing, and fertilization on density and biomass. Soil Biology \& Biochemistry 35:1079-1093.

Cooperative Agreement. 1997. Cooperative agreement for Platte River research and other efforts relating to endangered species habitats along the central Platte River, Nebraska. Signed July 1, 1997 by the Secretary of Interior and Governors of Nebraska, Wyoming, and Colorado.

Currier, P. J. 1997. Woody vegetation expansion and continuing declines in open channel habitat on the Platte River in Nebraska. Proceedings of the North American Crane Workshop 7:141-152.

Currier, P. J. and J. W. Ziewitz. 1986. Applications of a sandhill crane model to the management of habitat along the Platte River. p. 315-325. In J. C. Lewis (ed.) Proceedings of 1985 Crane Workshop. Platte River Whooping Crane Trust and U.S. Fish and Wildlife Service, Grand Island, NE, USA.

Curry, J. P. 1994. Grassland Invertebrates: Ecology, Influence on Soil Fertility and Effects on Plant Growth. Chapman and Hall, New York, NY, USA.

Curry, J. P. 1998. Factors affecting earthworm abundance in soils. p. 37-64. In C. A. Edwards (ed.) Earthworm Ecology. St. Lucie Press, New York, NY, USA.

Davidson, R. L. and R. J. Roberts. 1968. Influence of plants, manure, and soil moisture on survival and live weight gain in two scarabaeid larvae. Entomologia Experimentalis et Applicata 11:305314.

Davis, C. A. 1991. The ecology of macroinvertebrates inhabiting native grasslands and their role in the feeding ecology of sandhill cranes. M.S. Thesis. Iowa State University, Ames, IA, USA.

Davis, C. A. 2003. Habitat use and migration patterns of sandhill cranes along the Platte River, 1998-2001. Great Plains Research $13: 199-216$

Davis, C. A. and P. A. Vohs. 1993. Availability of earthworms and scarab beetles to sandhill cranes in native grasslands along the Platte River. Prairie Naturalist 25:199-212.

Edwards, C. A. and P. J. Bohlen. 1996. Biology and Ecology of Earthworms, third edition. Chapman and Hall, New York, NY, USA.

Edwards, C. A. and J. R. Lofty. 1977. Biology of Earthworms. John Wiley and Sons, New York, NY, USA.

Eschner, T., R. Hadley, and K. Crowley. 1981. Hydrologic and morphologic changes in the Platte River basin: a historical perspective. U.S. Geological Survey Open-file Report 81-1125.

Fender, W. M. 1985. Earthworms of the western United States. Part I. Lumbricidae. Megadrilogica 4:93-129.

Gerard, B. M. 1967. Factors affecting earthworms in pastures. Journal of Animal Ecology 36:235-252.

Hall, R. B. W. and P. A. Harcombe. 1998. Flooding alters apparent position of floodplain samplings on a light gradient. Ecology 79 : 847-855.

Hayes, D. C. and T. R. Seastedt. 1987. Root dynamics of tallgrass prairie in wet and dry years. Canadian Journal of Botany 65:787791.

Hendrix, P. F. and P. J. Bohlen. 2002. Exotic earthworm invasions in North America: ecological and policy implications. BioScience $52: 801-811$

Henszey, R. J. 1991. A simple, inexpensive device for measuring shallow groundwater levels. Journal of Soil and Water Conservation 46:304-306.

Henszey, R. J., K. Pfeiffer, and J. R. Keough. 2004. Linking surface and ground water levels to riparian grassland species along the Platte River in central Nebraska. Wetlands 24:665-687.

Hurr, R. T. 1983. Ground water hydrology of the Mormon Island Crane Meadows wildlife area near Grand Island, Hall County, Nebraska. U.S. Geological Survey Professional Paper 1277-H.
James, S. W. 1982. Effects of fire and soil type on earthworm populations in a tallgrass prairie. Pedobiologia 24:37-40.

Jansen, A. 1997. Terrestrial invertebrate community structure as an indicator of the success of a tropical rainforest restoration project. Restoration Ecology 5:115-124.

Jelinski, D. E. and P. J. Currier. 1996. Ecological risk assessment case study: middle Platte River floodplain, Nebraska. Office of Research and Development, U.S. Environmental Protection Agency, Washington, DC, USA.

Johnson, W. C. 1994. Woodland expansion in the Platte River, Nebraska: patterns and causes. Ecological Monographs 64:45-84.

Krapu, G. L., D. E. Facey, E. K. Fritzell, and D. H. Johnson. 1984. Habitat use by migrant sandhill cranes in Nebraska. Journal of Wildlife Management 48:407-417.

Lavelle, P. and A. V. Spain. 2001. Soil Ecology. Kluwer Academic Publishers, Boston, MA, USA.

Lee, K. E. 1985. Earthworms: Their Ecology and Relationships with Soil and Land Use. Academic Press, Orlando, FL, USA.

McCracken, D. I., G. N. Foster, and A. Kelly. 1995. Factors affecting the size of leatherjacket (Diptera: Tipulidae) populations in pastures in the west of Scotland. Applied Soil Ecology 2:203213.

McCune, B. and J. B. Grace. 2002. Analysis of ecological communities. MjM Software Design, Gleneden Beach, OR, USA.

McCune, B. and M. J. Mefford. 1999. PC-ORD. Multivariate analysis of ecological data, version 4. MjM Software Design, Gleneden Beach, OR, USA.

Milliken, G. A. and D. E. Johnson. 1992. Analysis of Messy Data, Volume I: Designed Experiments. Chapman and Hall, New York, NY, USA.

Nagel, H. G. and R. Harding. 1987. Effects of water table depth and soil factors on invertebrate populations. Prairie Naturalist 19:251258.

National Climatic Data Center. 2000. Local climatological data: annual summary with comparative data, Grand Island, Nebraska National Climatic Data Center, Asheville, NC, USA.

National Research Council. 2004. Endangered and threatened species of the Platte River. National Academies Press, Washington, DC, USA.

NWIS. 2003. NWISWeb data for the nation. http://waterdata. usgs.gov/nwis, U.S. Geological Survey, Washington, DC, USA. Retrieved on 26 May 2004.

Paris, O. H. 1963. The ecology of Armadillidium vulgare (Isopoda: Oniscoidea) in California grassland: food, enemies, and weather Ecological Monographs 33:1-22.

Peterson, H. 1982. Structure and size of soil animal populations. Oikos 39:306-329.

Pfeiffer, K. 1999. Evaluation of wet meadow restorations in the Platte River Valley. p. 202-206. In J. Springer (ed.) Proceedings of $16^{\text {th }}$ North American Prairie Conference. University of Nebraska, Kearney, NE, USA.

Ransom, M. D., C. W. Rice, T. C. Todd, and W. A. Wehmueller. 1998. Soils and soil biota. p. 48-66. In A. K. Knapp, J. M. Briggs, D. C. Hartnett, and S. L. Collins (eds.) Grassland Dynamics: Long-term Ecological Research in Tallgrass Prairie. Oxford University Press, Inc., New York, NY, USA.

Ratcliffe, B. C. 1991. The scarab beetles of Nebraska. Bulletin of the University of Nebraska State Museum 12:1-333.

Reinecke, K. J. and G. L. Krapu. 1986. Feeding ecology of sandhill cranes during spring migration in Nebraska. Journal of Wildlife Management 50:71-79.

Rice, C. W., T. C. Todd, J. M. Blair, T. R. Seastedt, R. A. Ramundo, and G. W. T. Wilson. 1998. Belowground biology and processes. p. 244-264. In A. K. Knapp, J. M. Briggs, D. C. Hartnett, and S L. Collins (eds.) Grassland Dynamics: Long-term Ecological Research in Tallgrass Prairie. Oxford University Press, Inc., New York, NY, USA.

Risser, P. G., C. E. Birney, H. D. Blocker, S. W. May, W. J. Parton, and J. A. Weins. 1981. The True Prairie Ecosystem. US/IBP Synthesis Series 16. Hutchinson Ross Publishing, Stroudsburg, PA, USA.

SAS Institute, Incorporated. 1999. SAS OnlineDoc ${ }^{\circledR}$, version 8. SAS Institute Inc., Cary, NC, USA. 
Seastedt, T. R. 1984. Belowground macroarthropods of annually burned and unburned tallgrass prairie. American Midland Naturalist 111:405-408.

Seastedt, T. R., and D. A. Crossley, Jr. 1984. The influence of arthropods on ecosystems. BioScience 34:157-161.

Seastedt, T. R., D. C. Hayes, and N. J. Petersen. 1986. Effects of vegetation, burning and mowing on soil macroarthropods of tallgrass prairie. p. 99-102. In G. K. Clambey and R. H. Pemble (eds.) Proceedings of the Ninth North American Prairie Conference. Tri-College University Center for Environmental Studies, Fargo, ND, USA.

Seastedt, T. R., T. C. Todd, and S. W. James. 1987. Experimental manipulations of arthropod, nematode, and earthworm communities in a North American tallgrass prairie. Pedobiologia 30:9-17.

Sidle, J. G., E. D. Miller, and P. J. Currier. 1989. Changing habitats in the Platte River valley of Nebraska. Prairie Naturalist 21:91104.

Stanton, N. L. 1988. The underground in grasslands. Annual Review of Ecology and Systematics 19:573-589.

Stehr, F. W. 1987. Immature Insects, Volume 1. Kendall/Hunt Publishing Company, Dubuque, IA, USA.

Stehr, F. W. 1991. Immature Insects, Volume 2. Kendall/Hunt Publishing Company, Dubuque, IA, USA.

ter Braak, C. J. F. 1986. Canonical correspondence analysis: a new eigenvector technique for multivariate direct gradient analysis. Ecology 76:1167-1179.

ter Braak, C. J. F. 1987. The analysis of vegetation-environment relationships by canonical correspondence analysis. Vegetatio 69 69-77.

Todd, T. C. 1996. Effects of management practices on nematode community structure in tallgrass prairie. Applied Soil Ecology 3: 235-246.

van Straalen, N. M. 1997. Community structure of soil arthropods as a bioindicator of soil health. p. 235-264. In C. Pankhurst, B. M. Doube, and V.V. S. R. Gupta (eds.) Biological Indicators of Soil Health. CAB International, New York, NY, USA.

Warburg, M. R. 1987. Isopods and their terrestrial environment. Advances in Ecological Research 17:87-242.

Wesche, T. A., Q. D. Skinner, and R. J. Henszey. 1994. Platte River wetland hydrology study: final report. Wyoming Water Resources Center Technical Report, University of Wyoming, Laramie, WY, USA.

Westerman, R. L. 1990. Soil Testing and Plant Analysis. Soil Science Society of America, Incorporated, Madison, WI, USA.

Whiles, M. R., B. S. Goldowitz, and R. E. Charlton. 1999. Life history and production of a semi-terrestrial limnephilid caddisfly in an intermittent Platte River wetland. Journal of North American Benthological Society 18:533-544.

Williams, G. P. 1978. The case of the shrinking channels-the North Platte and Platte Rivers in Nebraska. U.S. Geological Survey Circular 781

Manuscript received 20 May 2005; revisions received 14 October 2005; accepted 30 January 2006. 